\title{
Meningkatkan Hasil Belajar Siswa Kelas VIII dengan Metode Guided Discovery Learning di MTs Islamiyah Kotapinang
}

\author{
Improve Student Learning Outcomes with The Guided Discovery Learning \\ Method in the Class VIII MTs Islamiyah Kotapinang
}

\author{
Rohani $^{1}$, Indah Fitria Rahma ${ }^{2}$, Nurlina Ariani Hrp ${ }^{3}$ \\ ${ }^{123}$ Program Studi Pendidikan Matematika, STKIP Labuhan Batu, Jalan SM Raja No 126 A, Aek Tapa, Rantauprapat \\ Email:1pasariburohani@gmail.com, 2indahfitria286@gmail.com,3nurlinaariani@yahoo.com
}

\begin{abstract}
Abstrak
Penelitian ini bertujuan untuk mengetahui upaya meningkatkan hasil belajar siswa dengan metode guided discovery learning pada materi lingkaran kelas VIII MTs Islamiyah Kotapinang. Penelitian ini merupakan jenis Penelitian Tindakan Kelas. Objek Penelitian ini adalah upaya meningkatkan hasil belajar siswa dengan metode guided discovery learning pada materi lingkaran dan subjek penelitian ini adalah siswa kelas VIII MTs Swasta Islamiyah Kotapinang yang berjumlah 34 siswa. Hasil belajar matematika sebelum diterapkan metode guided discovery learning masih rendah karena dari 34 siswa yang mengikuti tes belajar awal, hanya 14 siswa yang tuntas $(41,18 \%)$. Setelah diterapkan metode guided discovery learning hasil belajar siswa mengalami peningkatan. Berdasarkan tes hasil belajar siklus I, diperoleh nilai rata-rata kelas 56,47 dengan 27 siswa $(79,41 \%)$ mencapai ketuntasan belajar dan 7 siswa $(20,59)$ belum mencapai ketuntasan belajar. Dengan melihat persentase klasikal belum mencapai $\geq 85 \%$ maka siklus I belum mencapai ketuntasa secara klasikal. Untuk memperbaiki pelaksanaan siklus I dilaksanakan tindakan siklus II. Pada tes hasil belajar siklus II nilai rata-rata kelas 73,24 dengan 31 siswa $(91,18 \%)$ mencapai ketuntasa belajar sedangkan 3 siswa $(8,82 \%)$ belum mencapai ketuntasan belajar. Dengan melihat persentase klasikal telah mencapai $\geq 85 \%$ maka kelas ini dapat dinyatakan tuntas secara klasikal. Berdasarkan hasil yang diperoleh, dapat ditarik kesimpulan bahwa upaya meningkatkan hasil belajar siswa dengan metode guided discovery learning dapat meningkatkan hasil belajar matematika.
\end{abstract}

\section{Kata Kunci : Metode Guided Discovery Learning, Hasil belajar}

\begin{abstract}
The Aim of this study aims to determine the remedy to mount the result of student learning with method guided discovery learning on the matter lingkaran in class VIII MTs Swasta Islamiyah Kotapinang. This research is Classroom Action Research. Object of this research is the remedy to amount the result of student learning with method guided discovery learning on the matter lingkaran the subjects of this research are student of MTs Swasta Islamiyah Kotapinang VIII ${ }^{2}$, Amounting to 34 students. The result of mathematical studies before implementation methode the guided discovery learning of is still low because of the 34 students who take the test early study, only 14 were ompleted $(41,18 \%)$. Once applied the method of guided discovery learning student learning outcomes has increased. Based on the test result of the first cycle of learning, the value of the average grade 56,47 with 27 students $(71,42 \%)$ achieved a passing grade and 7 students $(20,59 \%)$ have not reached complete learned. By looking at the percentage of classical yet to reach $\geq 85 \%$ of the cycle I have not reached completeness in the classical style. To improve implementation of the first cycle of the second cycle executed. In cycle II achievement test score average of 73,24 grade with 31 students (91,18\%) achieved a complete learn while 3 students $(8,82 \%)$ have not reached complete learned. By looking at the percentage of classical has reached $\geq 85 \%$ then this class can be declared complete in classical.Based on the result obtained, it can be concluded that the application of the methode guided discovery learning can improve the result of learning mathematic.
\end{abstract}

Keywords: Methode Guided Discovery Learning, The Result Learning

Rohani', Indah Fitria Rahma², Nurlina Ariani Hrp

Meningkatkan Hasil Belajar Siswa Kelas VIII dengan Metode Guided Discovery Learning

di MTs Islamiyah Kotapinang 


\section{Pendahuluan}

Usaha pemerintah telah banyak untuk membenahi proses pembelajaran seperti penataran Guru, membantu Musyawarah Bidang Studi, perbaikan kurikulum, bantuan alat-alat laboratorium, tetapi secara umum hasil belajar yang di capai oleh siswa SMP, khususnya Bidang Studi Matematika masih rendah atau belum memuaskan, ada banyak faktor penyebab rendahnya hasil belajar siswa di antaranya adalah faktor guru, siswa lingkungan, masyarakat, strategi mengajar, metode belajar dan lain-lain.

Oleh karena itu guru hendaknya tidak lagi sekedar mengajar sebagai kegiatan menyampaikan pengetahuan, keterampilan dan sikap pada siswa, penelitian ini membahas perbaikan metode pembelajaran yaitu dengan menggunakan metode Pembelajaran, kaitannya dengan hasil belajar matematika siswa Madrasah Tsanawiyah, Metode adalah sesuatu yang dibutuhkan untuk melakukan aktivitas.

Observasi awal yang dilakukan oleh peneliti di kelas VIII ${ }^{2}$ MTs Swasta Islamiyah Kotapinang, peneliti mengadakan pertemuan dengan guru-guru dan guru bidang studi matematika mengadakan pengidentifikasian bersama terhadap permasalahan-permasalahan yang muncul selama proses belajar mengajar di dalam kelas.Berdasarkan hasil observasi dan wawancara dengan guru serta melihat nilai rata-rata matematika siswa khususnya materi lingkaran kelas VIII ${ }^{2}$ MTs Swasta Islamiyah Kotapinang tiga tahun terakhir yaitu sebesar 68.1. Bila dibandingkan dengan mata pelajaran lain hasil belajar matematika merupakan hasil belajar yang paling rendah, seperti yang terlihat pada tabel berikut:

Tabel 1.1 Hasil Belajar Matematika kelas VIII² MTs Swasta Islamiyah Kotapinang

\begin{tabular}{|l|c|}
\hline \multicolumn{1}{|c|}{ Mata Pelajaran } & Kelas VIII $^{2}$ \\
\hline Matematika T.A 2012 / 2013 & 67.4 \\
\hline Matematika T.A 2013 / 2014 & 69.5 \\
\hline Matematika T.A 2014 / 2015 & 67.4 \\
\hline \multirow{2}{*}{ JUMLAH } & 204.3 \\
\hline RATA - RATA & 68.1 \\
\hline
\end{tabular}

Selain rendahnya nilai rata-rata matematika, peserta didik juga memiliki kecendrungan menghafal dari pada memahami materi-materi pelajaran yang diberikan guru. Dari hal di atas terlihat bahwa siswa tidak bisa menjawab soal yang diberikan dengan menggunakan apa yang selama ini mereka hafal. Temuan lain selama kegiatan belajar mengajar adalah ketika guru meminta kelompok siswa mendiskusikan hasil kerjanya di depan kelas, kegiatan diskusi kelas hanya didominasi oleh 2-3 orang siswa sedangkan yang lainnya cenderung berlaku datang, duduk, dengar, dan diam.

Metode Pembelajaran Discovery Learning memungkinkan agar perkembangan pengetahuan anak didik meningkat, dan menciptakan suasana lingkungan memungkinkan siswa melaksanakan kegiatan belajar matematika, dan proses belajar Metode Pembelajaran Discovery Learning berpusat pada siswa dengan melibatkan partisipasi aktif peserta didik.

Siswa akan terdorong untuk belajar, manakala siswa memiliki minat untuk belajar. Beberapa cara dapat dilakukan untuk membangkitkan minat belajar siswa diantaranya: (1) Hubungkan bahan pelajaran yang akan diajarkan dengan kebutuhan siswa. Minat siswa akan tumbuh manakala ia dapat menangkap bahwa materi pelajaran itu berguna untuk kehidupannya; (2) sesuaikan materi pelajaran dengan tingkat pengalaman dan kemampuan siswa. Materi pelajaran yang terlalu sulit untuk dipelajari atau materi pelajaran yang jauh dari pengalaman siswa, akan tidak diminati siswa; dan (3) gunakan pelbagai model dan metode pembelajaran secara bervariasi misalnya diskusi, kerja kelompok, eksperimen, demonstrasi, dan lain sebagainya[1]

Guru sebagai evaluator berperan untuk meningkatkan minat belajar siswa. Sebagaimana yang diungkapkan bahwa Minat besar pengaruhnya terhadap belajar, karena bila bahan pelajaran yang dipelajari tidak sesuai dengan minat siswa, siswa tidak akan belajar sebaik-baiknya karena tidak ada daya tarik baginya. [2] 


\section{Metode Penelitian \\ Jenis Penelitian}

Ada dua jenis penelitian, yaitu penelitian kuantitatif dan penelitian kualitatif. Penelitian kuantitatif mengacu pada anggapan bahwa suatu gejala sosial dapat diukur dan diubah dalam bentuk angka, sehingga dapat dilakukan perhitungan statistik untuk menganalisis data baik untuk keperluan deskriptif maupun untuk uji hipotesis, dan membuat kesimpula. Sedangkan menurut Bogman dan Taylor (dalam penelitian kualitatif adalah sebagai prosedur penelitian yang menghasilkan data deskriptif berupa kata-kata tertulis atau lisan dari orang-orang dan perilaku yang diamati, menurut mereka kita tidak boleh mengisolasi individu atau organisasi kedalam variabel atau hipotesis, tetapi perlu memandang sebagai bagian keutuhan[3]

Penelitian ini menggunakan pendekatan penelitian kuantitatif dengan metode eksperimen dalam bentuk kuasi eksperimen. Penelitian eksperimen menurut penelitian yang benar-benar untuk melihat hubungan sebab-akibat[4]. Perlakuan yang kita lakukan terhadap variabel bebas kita lihat hasilnya pada variabel terikat. Penelitian ini bertujuan menelaah tentang hasil belajar dan sikap siswa yang dipengaruhi oleh model pembelajaran yaitu Pembelajaran berbasis masalah (PBM) dan pembelajaran konvensional.

\section{Populasi dan Sampel}

a. Populasi

Populasi dalam penelitian ini adalah seluruh siswa kelas VIII VIII ${ }^{2}$ MTs Swasta Islamiyah Kotapinan. Selain itu menurut observasi sekolah ini kemampuan siswanya juga beragam, serta di sekolah ini belum ada yang meneliti tentang model Pembelajaran berbasis masalah (PBM).

\section{b. Sampel}

Kelas yang tepilih menjadi sampel, diambil secara acak dua kelas dengan dengan kemampuan sama untuk menetapkan kelas sampel. Hal ini dilakukan karena peneliti tidak mungkin mengambil siswa secara acak untuk membentuk kelas baru maka peneliti mengambil unit sampling terkecilnya yaitu siswa kelas $V I I I^{1} \mathrm{VIII}{ }^{2}$ MTs Swasta Islamiyah Kotapinang sebagai kelas eksperimen dan siswa kelas $V I I I^{4}$ sebagai kelas kontrol.

\section{Data dan Teknik Pengumpulan Data \\ 1. Jenis Data Dan Sumber Data}

Terkait dengan penelitian ini yang akan dijadikan sebagai sumber data adalah siswa-siswi kelas $V I I I^{1} \mathrm{VIII}^{2}$ MTs Swasta Islamiyah Kotapinang sebagai kelas eksperimen dan $\mathrm{VIII}^{4}$ sebagai kelas kontrol.

Data penelitian ini mencakup:

1. Nilai tes hasil belajar matematika siswa setelah mengerjakan soal-soal yang diberikan guru pada akhir pembelajaran.

2. Hasil lembar respon siswa terhadap pembelajaran Pembelajaran Berbasis Masalah.

3. Hasil observasi aktivitas guru dan siswa pada pembelajaran berlangsung.

Data yang diperoleh dari penelitian tindakan ini ada yang bersifat kualitatif dan kuantitatif. Data yang bersifat kualitatif diperoleh dari: (1) lembar respon siswa, (2) observasi aktivitas guru dan siswa, (3) interview, sedangkan data yang bersifat kuantitatif berasal dari nilai tes hasil hasil belajar siswa dan lembar observasi. Adapun instrumen penelitian yang digunakan pada penelitian ini adalah sebagai berikut:

\section{Angket sikap Siswa}

Angket (Questioner) merupakan instrumen di dalam teknik komunikasi tidak langsung. Dengan instrumen ini data yang dapat dihimpun bersifat informatif dengan atau tanpa penjelasan atau interpretasi berupa pendapat, buah pikiran, penilaian, ungkapan perasaan, dan lain-lain. Angket yang di isi oleh responden merupakan instrumen yang dapat dipergunakan dalam penelitian,

Angket dalam penelitian ini digunakan untuk mengumpulkan informasi tentang sikap siswa terhadap kegiatan dan perangkat pembelajaran PBM dengan memberikan tanda cek $(\sqrt{ })$ pada kolom yang tersedia untuk setiap pernyataan yang diberikan. Angket berisi tentang garis-garis pokok yang ditanyakan dengan maksud agar peserta didik mengungkapkan tanggapannya terhadap pembelajaran Matematika dengan PBM. Angket ini menggunakan instrumen yang disusun peneliti dengan menggunakan empat kategori sangat setuju (SS), setuju (S), tidak setuju (TS), dan sangat tidak setuju (STS). Angket sikap siswa diberikan kepada siswa pada akhir penelitian ini.

2. Lembar Soal hasil belajar

Soal terdiri dari 5 soal uraian untuk mengetahui kemampuan kognitif siswa. 
3. Lembar Observasi Siswa Guru dan Siswa pada Pembelajaran Pembelajaran Berbasis Masalah (PBM).

Lembar observasi menggunakan tabel pedoman observasi untuk mengetahui tingkat aktivitas guru dan aktivitas siswa pada saat pembelajaran berlangsung dengan memberikan tanda silang pada kolom yang sesuai.

\section{Teknik Pengumpulan Data}

Teknik pengumpulan data tes hasil belajar siswa, lembar sikap siswa, dan lembar observasi aktivitas guru dan siswa terhadap kegiatan pembelajaran. Semua data akan dinalisis untuk penarikan kesimpulan.

1. Nilai tes hasil hasil belajar siswa setelah mengerjakan soal-soal yang diberikan guru pada setiap akhir siklus yang terdiri dari 5 soal uraian pada masing-masing siklus yang berfungsi untuk mengetahui hasil belajar siswa.

2. Hasil lembar sikap siswa terhadap pembelajaran Pembelajaran Berbasis Masalah (PBM) yang diberikan guru terhadap siswa yang terdiri dari 25 butir pertanyaan dengan memberikan tanda cek $(\sqrt{ })$ pada kolom yang tersedia untuk setiap pernyataan yang diberikan.

3. Hasil observasi aktivitas guru dan siswa pada pembelajaran berlangsung. Lembar observasi menggunakan tabel pedoman observasi untuk mengetahui tingkat aktivitas guru dan aktivitas siswa pada saat pembelajaran berlangsung dengan memberikan 17 pertanyaan dan setiap pertanyaan diberi tanda silang pada kolom yang sesuai.

\section{Analisis Data}

Data yang dianalisis adalah data hasil yang diperoleh dari hasil LKS yang telah disesuaikan dengan skor masing-masing tiap indikator pembelajaran.

a. Tes Hasil belajar

Tes yang dilakukan berbentuk essay sebanyak 5 soal yang dilaksanakan pada setiap akhir pembelajaran, hasil tes ini akan digunakan untuk mengetahui peningkatan hasil belajar siswa melalui Pembelajaran Berbasis Masalah (PMB). Skor Hasil belajar siswa diperoleh dari hasil skor yang diperoleh dibagi dengan skor maksimal dikalikan dengan 100, dirumuskan sebagai berikut:

$$
S K B=\frac{\text { Skor Diperoleh }}{\text { Skor Maksimal }} \times 100
$$

Secara individual, siswa dikatakan telah mampu memecahkan masalah jika Skor Hasil belajar yang diperoleh minimal mencapai kategori "cukup baik". Selanjutnya, suatu kelompok dikatakan telah mampu belajar (kemampuan klasikal) jika terdapat minimal 80\% siswa telah memiliki Skor Hasil belajar dengan minimal mencapai kategori cukup baik.

b. Angket Sikap Siswa

Setelah semua data yang diperlukan telah terkumpul, dilanjutkan dengan pengolahan data tersebut sebagai bahan untuk menjawab permasalahan yang ada dalam penelitian. Adapun prosedur untuk pengolahan datanya sebagai berikut :

1. Analisis data tes awal (pretes) :

a. Menghitung nilai rerata kelas eksperimen dan kelas kontrol.

b. Menghitung simpangan baku kelas eksperimen dan kelas kontrol

c. Melakukan uji normalitas kepada kedua kelas tersebut

d. Jika tidak normal, maka dilakukan uji statistik non-parametrik dengan menggunakan tes Mann-Whitney U-Test.

e. Melakukan uji homogenitas dua varians.

f. Melakukan uji kesamaan dua rerata dengan menggunakan uji-t tetapi jika tidak homogen dilanjutkan dengan tes t'.

2. Analisis data tes akhir (postes) :

a. Menghitung nilai rerata kelas eksperimen dan kelas kontrol

b. Menghitung simpangan baku kelas eksperimen dan kelas kontrol

c. Melakukan uji normalitas kepada kedua kelas tersebut

d. Jika tidak normal, maka dilakukan uji statistik non-parametrik dengan menggunakan tes Mann-Whitney U-Test.

e. Melakukan uji homogenitas dua varians.

f. Melakukan uji kesamaan dua rerata dengan menggunakan uji-t tetapi jika tidak homogen dilanjutkan dengan tes t'. 


\section{Hasil Penelitian \\ Deskripsi Hasil belajar}

Tes hasil belajar dilakukan dua kali yaitu uji awal dan uji akhir dengan soal yang ekuivalen. Tes awal dan akhir diikuti 32 orang siswa sehingga dalam analisis data yang menjadi subyek penelitian ini adalah 32 orang yaitu yang mengikuti tes awal dan tes akhir.

Rata-rata skor siswa terhadap materi Melakukan menyelesaikan sistem persamaan linier dua variabel kelas eksperimen dirangkum dalam Tabel berikut.

\begin{tabular}{|c|c|c|c|c|}
\hline Jenis Tes & No & Aspek & \multicolumn{2}{|c|}{ Kelompok } \\
\cline { 4 - 5 } $\begin{array}{c}\text { Pemecahan } \\
\text { Masalah }\end{array}$ & 1 & $\begin{array}{c}\text { Proporsi } \\
\text { skor uji } \\
\text { awal }\end{array}$ & 1,14 & 1.11 \\
\cline { 2 - 5 } & 2 & $\begin{array}{c}\text { Proporsi } \\
\text { skor uji } \\
\text { akhir }\end{array}$ & 6,08 & 6,94 \\
\cline { 2 - 5 } & 3 & $\begin{array}{c}\text { Jumlah } \\
\text { siswa yang } \\
\text { tuntas }\end{array}$ & 18 & 28 \\
\cline { 2 - 5 } & 4 & $\begin{array}{c}\text { \% } \\
\text { Ketuntasan }\end{array}$ & 56,25 & 87,5 \\
\hline
\end{tabular}

Pada Tabel diatas dapat dilihat, untuk hasil belajar rata-rata proporsi skor uji awal dan uji akhir siswa kelas kontrol adalah 1,14 dan 6,08. Bila diperhatikan rata-rata proporsi skor uji akhir terjadi peningkatan rata-rata proporsi skor sebesar 4,94. Sedangkan kelompok eksperimen yaitu 1,11 dan 6,94 terjadi peningkatan rata-rata proporsi skor sebesar 5,83 . Selisih proporsi uji awal dan uji akhir kelompok eksperimen lebih besar dari selisih proporsi skor uji awal dan uji akhir untuk kelas kontrol. Hal ini memberi petunjuk bahwa pembelajaran berbasis masalah dapat meningkatkan pencapaian hasil belajar matematika daripada pengajaran konvensional.

Menurut data pada Tabel kriteria ketuntasan belajar untuk hasil belajar bahwa banyaknya siswa kelas kontrol yang tuntas belajar hanya 18 orang dari 32 siswa atau 56,25\% dari jumlah siswa. Banyaknya siswa yang tuntas untuk kelas eksperimen adalah 28 orang dari 32 siswa atau $87,5 \%$ dari jumlah siswa. Selisih persentase ketuntasan siswa kelas eksperimen ini jauh lebih besar dari persentase ketuntasan siswa kelas kontrol dengan sebesar $28,12 \%$. Selisih persentase ketuntasan siswa kelas eksperimen ini jauh lebih besar dari persentase ketuntasan siswa kelas kontrol dengan sebesar $15,63 \%$.

Hasil tersebut menunjukkan bahwa pembelajaran berbasis masalah yang didukung perangkat pembelajaran yang dikembangkan peneliti dapat meningkatkan jumlah siswa yang tuntas belajar untuk materi melakukan menyelesaikan sistem persamaan linier dua variabel.

Berdasarkan data hasil uji awal dengan uji akhir siswa kelas kelas eksperimen untuk hasil belajar diperoleh: persamaan regresi $Y_{E}=29,69+0,91 X_{E}$. Untuk menguji keberartian koefisien persamaan regresi tersebut dirumuskan hipotesis sebagai berikut:

$$
\mathrm{H}_{0}: \theta_{4}=0 \text { dan } \mathrm{H}_{a}: \theta_{4} \neq 0
$$

Untuk menguji hipotesis tersebut digunakan analisis varians dengan menggunakan statistik $\mathrm{F}$ dengan rumus dan kriteria yang ditetapkan. Hasil analisis uji indepedensi pada kelas eksperimen diperoleh $\mathrm{F}$ ${ }^{*}=8,79$ dan berdasarkan Tabel $\mathrm{F}$, untuk $\alpha=5 \%$ diperoleh: $\mathrm{F}_{(1-\alpha, 1: n-2)}=\mathrm{F}_{(0.95,1,30)}=4,15$. Berarti F

* $\geq \mathrm{F}_{(0.95,1,30)} . \mathrm{H}_{0}$ ditolak dan diterima $\mathrm{H}_{a}$. Artinya ada pengaruh positif (signifikansi) hasil uji awal hasil belajar siswa $(X)$ terhadap hasil uji akhir siswa $(Y)$ untuk kelas eksperimen. Artinya ada pengaruh positif (signifikansi) hasil uji awal hasil belajar siswa $(X)$ terhadap hasil uji akhir siswa $(Y)$ untuk kelas eksperimen.

Sementara hasil perhitungan uji independensi dan koefisien hasil belajar matematika kelas eksperimen dan kelas kontrol dengan menggunakan program SPSS diperoleh dari ANOVA atau $F$ test, untuk hasil belajar kelas eksperimen didapat $\mathrm{F}$ hitung adalah 8,794 dengan tingkat signifikansi 0,006 . Karena probabilitas $(0,006)$ jauh lebih kecil dari 0,05 , maka model regresi bisa dipakai dengan persamaan regrsi $Y=29,69+0,91 X$.

Uji Linieritas Persamaan Regresi Kelas Eksperimen

Rohani ${ }^{1}$ Indah Fitria Rahma², Nurlina Ariani Hrp

Meningkatkan Hasil Belajar Siswa Kelas VIII dengan Metode Guided Discovery Learning

di MTs Islamiyah Kotapinang 

hipotesis:

Akan diuji kecocokan model regresi linier untuk hasil belajar $Y_{E}=29.33+0.94 X_{E}$ dengan

$\mathrm{H}_{0} \quad$ : Model regresi adalah linier

$\mathrm{H}_{a} \quad$ : Model regresi adalah tidak linier

Untuk menguji hipotesis di atas dilakukan dengan analisis varians dengan menggunakan statistik- $\mathrm{F}$ dengan rumus dan kriteria yang ditetapkan. Hasil analisis uji linieritas pada kelas ekperimen disajikan pada Tabel berikut:

\begin{tabular}{|c|c|c|c|c|}
\hline $\begin{array}{c}\text { Source of } \\
\text { Varians }\end{array}$ & Df & SS & MS & F' \\
\hline Error & 30 & $\mathrm{JK}_{\text {reg }}=639.975$ & $\mathrm{~S}_{\text {reg }}^{2}=21.333$ & \\
Lack of Fit & 10 & 270.175 & $\mathrm{~S}_{T C}^{2}=27.018$ & 1.461 \\
Pure Error & 20 & 369.800 & $\mathrm{~S}_{\epsilon}^{2}=18.490$ & \\
\hline
\end{tabular}

Berdasarkan data pada Tabel hasil belajar diperoleh $F^{*}=1,461$ dan berdasarkan Tabel $F$, untuk $\alpha=5 \%$ diproleh: $\mathrm{F}_{(1-\alpha, c-2, n-c)}=\mathrm{F}_{(0.95,10,20)}=2.35$. Berarti $\mathrm{F}^{*}<\mathrm{F}_{(0.95,9,21)} \cdot \mathrm{H}_{0}$ diterima atau model regresi kelas kontrol adalah linier. Artinya ada hubungan antara hasil uji awal dengan uji akhir siswa kelas kontrol dapat ditunjukkan dengan model regresi linier dengan persamaan regresi untuk kemampuan pemecahan $Y_{E}=29.33+0.94 X_{E}$. Dengan kata lain, hubungan antara hasil uji awal dengan uji akhir siswa kelas eksperimen dapat dinyatakan dengan model regresi linier atau model regresi yang diajukan adalah cocok.

Instrumen Observasi Guru dan Siswa serta Respon Siswa

Selain aspek-aspek yang diamati secara langsung di kelas, untuk melihat ide, gagasan dan perasaaan siswa dan bagaimana tanggapan siswa tentang pembelajaran Pembelajaran Berbasis Masalah maka kepada guru dan siswa diberikan lembar observasi siswa. Berikut adalah hasil pengumpulan data dari instrumen observasi kegiatan siswa, kegiatan guru dan angket respon siswa.

\section{Hasil Observasi Kegiatan Guru}

Hasil observasi kegiatan guru yang diperoleh diketahui bahwa nilai rata-rata untuk masingmasing aspek yang diamati dengan nilai maksimum adalah lima, diperoleh hasil observasi kegiatan guru jika diurutkan dari yang tertinggi ke terendah yaitu kegiatan inti $(4,61)$, penutup $(4,60)$, pendahuluan $(4,50)$, dan pengelolaan waktu $(4,50)$.

Secara keseluruhan diperoleh rata-rata $91,76 \%$, berdasarkan kriteria skor pada bab III maka $91,76 \%$ termasuk dalam kategori 'sangat baik'. Maka dapat disimpulkan bahwa kegiatan guru adalah sangat baik.

\section{Hasil Observasi Kegiatan Siswa}

Hasil observasi kegiatan siswa yang secara keseluruhan pada siklus II diperoleh rata-rata 90,00 $\%$, berdasarkan kriteria skor pada bab III maka $90,00 \%$ termasuk dalam kategori 'sangat baik'. Maka dapat disimpulkan bahwa kegiatan siswa adalah sangat baik.

\section{1) Respon Siswa terhadap Pembelajaran}

Hasil respon siswa terhadap pembelajaran Pembelajaran Berbasis Masalah berdasarkan indikator respon siswa pada kisi-kisi menunjukkan data sebagai berikut : (1) Sebagian besar $(88,62 \%)$ siswa suka terhadap pelajaran matematika, (2) Sebagian besar (95\%) siswa sungguh-sungguh mengikuti pelajaran matematika yang dilakukan, (3) Sebagian besar (88\%) siswa suka terhadap model pembelajaran Pembelajaran Berbasis Masalah, (4) Sebagian besar $(93,21 \%)$ siswa menyatakan bahwa model pembelajaran Pembelajaran Berbasis Masalah bermanfaat; (5) Sebagian besar $(88,92 \%)$ siswa suka terhadap LKS.

\section{Pembahasan \\ Hasil belajar Matematika}

Rohani', Indah Fitria Rahma ${ }^{2}$, Nurlina Ariani Hrp ${ }^{3}$

Meningkatkan Hasil Belajar Siswa Kelas VIII dengan Metode Guided Discovery Learning

di MTs Islamiyah Kotapinang 
Seperti telah dikemukakan sebelumnya, bahwa yang dimaksud dengan hasil belajar adalah kemampuan siswa untuk memahami masalah, merencanakan pemecahan masalah, melakukan perhitungan dan memeriksa kembali. Hasil penelitian menunjukkan, pencapaian ketuntasan hasil hasil belajar dan siswa dengan pembelajaran berbasis masalah jauh lebih besar daripada kelas yang dikenai pengajaran langsung. Ketuntasan belajar tercapai pada kelas ekperimen, yaitu terdapat 28 orang dari 32 siswa atau $87,5 \%$ dari jumlah siswa di kelas eksperimen yang tuntas belajar berdasarkan kriteria ketuntasan belajar kurikulum. Sedangkan pada kelas kontrol terdapat 18 siswa atau $56,25 \%$.

Model pembelajaran berbasis masalah secara signifikan telah berhasil meningkatkan hasil belajar matematika siswa jika dibandingkan dengan pengajaran langsung. Hasil penelitian dilihat dari konstanta persamaan regresi untuk pembelajaran berbasis masalah yaitu 29,69 sedangkan pengajaran langsung 24,56 .

Ditinjau aspek memahami masalah terdapat pada semua nomor soal, untuk pembelajaran berbasis masalah hanya 20 siswa dari 32 siswa dapat menjawab soal dengan benar sedangkan pada pengajaran langsung terdapat 10 siswa. Jumlah siswa yang mampu memahami masalah pada pembelajaran berbasis masalah lebih banyak daripada pengajaran langsung karena pada salah satu karekteristik pembelajaran berbasis masalah adalah pengajuan masalah kontekstual sehingga membuat siswa dapat berpikir kritis. Sedangkan pada pengajaran langsung, siswa hanya mengikuti penyelesaian yang telah dibuat guru. Kesulitan siswa tidak mengetahui data tersebut cukup atau tidak untuk menyelesaikan soal tersebut. Dari hasil wawancara, mereka hanya menebak saja.

Dalam aspek merencanakan penyelesaian, untuk pembelajaran berbasis masalah terdapat 22 siswa yang menuliskan model matematika atau memisalkannya dengan suatu variabel tertentu secara lengkap sedangkan pada pengajaran langsung terdapat 17 siswa. Di kelas berbasis masalah dijelaskan apa arti variabel $x$. Adapun langkah pembuatan rencana yang benar untuk soal-soal pemecahan masalah yaitu, pertama dengan membuat pemisalan dari apa yang diketahui dalam bentuk dua variabel. Selanjutnya membuat persamaan matematikanya dalam bentuk persamaan. Kemudian membuat perencanaan untuk menyelesaikan masalah yaitu mencari nilai variabel yang dimisalkan tadi. Di kelas pengajaran langsung kebanyakan siswa langsung menyelesaikan soal tanpa menuliskan model matematikannya. Sehingga rata-rata jawaban siswa kelompok pembelajaran berbasis masalah memiliki jawaban yang lebih baik dan masuk akal jika dibandingkan dengan kelompok pengajaran langsung.

Aspek melakukan perhitungan, ada beberapa soal yang dikerjakan siswa dengan lengkap, ada juga yang salah dalam melakukan perhitungan (penjumlahan dan pembagian). Untuk mencari penyelesaian masalah (jawaban) para siswa harus mampu memanfaatkan pengetahuan mereka. Penyelesaian akhir (jawaban) bukanlah tujuan akhir dari pembelajaran matematika, melainkan sebagai bagian terbesar dari aktivitas. Dari penelitian ini jumlah siswa yang menuliskan penyelesaian masalah secara lengkap dan benar pada pembelajaran berbasis masalah sebanyak 25 siswa sedangkan pada pengajaran langsung terdapat 16 siswa. Variasi jawaban di kelas eksperimen lebih banyak dibandingkan dengan kelompok kontrol.

Aspek memeriksa kembali, pada pembelajaran berbasis masalah terdapat 18 siswa yang mampu menuliskannya, kebanyakan siswa hanya menuliskan "Benar", sedangkan pada pengajaran langsung terdapat 10 siswa. Di kelas berbasis masalah ragam siswa dalam memeriksa kembali jawaban yang diperoleh beragam sedangkan pada kelas pengajaran langsung hanya sebagian kecil siswa yang mampu. Siswa tidak mampu melakukan pengecekan kembali hasil yang diperoleh, menelaah kembali proses penyelesaian yang telah dibuat.

\section{Observasi dalam Proses Pembelajaran Berbasis Masalah}

Dari hasil analisis deksriftif data observasi siswa dan berdasarkan kriteria yang ditetapkan diperoleh kesimpulan bahwa aktivitas siswa dalam pembelajaran berbasis masalah adalah efektif. Aktivitas siswa dalam pembelajaran berbasis masalah meliputi: orientasi masalah, mengorganisasikan siswa untuk belajar, membimbing penyelidikan individu maupun kelompok, mengembangkan dan menyajikan hasil karya, menganalisis dan mengevaluasi proses pemecahan masalah.

Aktivitas siswa pada orientasi masalah terdiri dari membaca/memahami LKS dan memperhatikan penjelasan guru. Rata-rata aktivitas siswa membaca/memahami masalah sebesar 4 dan memperhatikan penjelasan guru sebesar 4. Masalah-masalah yang dijadikan sebagai sarana belajar adalah masalah yang memenuhi konteks dunia nyata (real world), yang akrab dengan kehidupan sehari-hari para siswa. Melalui masalah-masalah kontekstual ini para siswa menemukan kembali pengetahuan konsep-konsep dan ide-ide yang esensial dari materi pelajaran dan membangunnya ke dalam stuktur kognitf, menuntut siswa untuk menggunakan beragam pengetahuan yang telah dimiliki sebelumnya serta mengkonstruksi cara atau prosedur, coba ini dan coba itu,

Rohani', Indah Fitria Rahma ${ }^{2}$, Nurlina Ariani Hrp ${ }^{3}$

Meningkatkan Hasil Belajar Siswa Kelas VIII dengan Metode Guided Discovery Learning

di MTs Islamiyah Kotapinang 
sebelum mendapatkan jawaban. Guru dalam pembelajaran ini bukan pemberi jawaban tetapi hanya sebagai fasilitator.

Aktivitas yang kedua yaitu mengorganisir siswa untu belajar terdiri dari diskusi antar siswa dan diskusi antar guru dengan nilai rata-rata 4 dan 4 . Pembelajaran berbasis masalah dengan komponen masyarakat belajar (learning community) menekankan pada hakekat sosiokultural menurut siswa saling berinteraksi baik terhadap guru maupun teman satu kelompok. Siswa yang mempunyai kemampuan yang lemah ikut aktif berdiskusi/bertanya dengan siswa yang memiliki kemampuan yang tinggi. Hal ini sesuai pendapat Vygotsky yakin bahwa fungsi mental yang lebih tinggi pada umumnya muncul dalam percakapan atau antar individu sebelum fungsi mental yang lebih tinggi itu terserap ke dalam individu tersebut. Aktivitas ketiga, yaitu membimbing penyelidikan individu maupun kelompok yang terdiri dari mengajukan pertanyaan dan menyelesaikan masalah. Diperoleh nilai rata-rata untuk mengajukan pertanyaan 4 dan menyelesaikan masalah 4 . Dengan adanya masalah membuat siswa lebih tertantang untuk mengetahui cara menyelesaikan masalah tersebut. Keingintahuan ini, memotivasi mereka untuk membangun pengetahuan mereka secara aktif representatif-representatif di benaknya tentang lingkungan yang mereka alami. Dalam proses pembelajaran ini peran guru bukan sebagai pemberi jawaban atas pertanyaan pertanyaan mereka. Guru menggunakan teknik scaffolding dan pengajuan petunjuk (clue). Dalam teknik scaffolding guru dituntut terampil menggunakan teknik bertanya, diantaranya yang sangat penting adalah memecah pertanyaan yang kompleks bagi siswa menjadi pertanyaan-pertanyaan yang lebih sederhana terjangkau pikiran siswa pada saat itu.

Aktivitas keempat yaitu mengembangkan dan menyajikan hasil karya, diperoleh nilai rata-rata sebesar 4. Dari hasil diskusi antara sesama anggota kelompok, siswa menampilkan hsil karya atau hasil diskusi yang mereka peroleh di depan kelas untuk memperoleh masukan dari hasil yang mereka buat dan saling berbagi ide untuk mengajukan penyelesaian yang baik. Dengan demikian siswa dengan mudah dapat menemukan kesalahan-kesalahan pada penyelesaian masalah yang dibuat. Bagi siswa mempunyai kesempatan untuk berlatih menyampaikan ide dan gagasan kepada orang lain dan menghargai pendapat orang lain sehingga sangat memungkinkan dapat menambah pengetahuan mereka. Hal ini juga disampaikan oleh Piaget menyatakan bahwa interaksi sosial, terlebih interaksi dengan teman-teman satu kelompok maupun di luar kelompok mempunyai pengaruh besar dalam pemikiran anak[5]. Dengan interaksi ini, seorang anak dapat membandingkan pemikiran dan pengetahuan yang telah dibentuknya dengan pemikiran dan pengetahuan orang lain.

Aktivitas kelima yaitu menganalisis dan mengevaluasi proses pemecahan masalah, yang terdiri dari mencatat hal-hal yang relevan dengan KBM, membuat kesimpulan, dan portofolio menyelesaikan PR dan hasil karya dengan perolehan nilai rata-rata sebesar 4. Dalam aktivitas ini membantu siswa menganalsis dan mengevaluasi proses berpikir mereka sendiri maupun keterampilan investigatif dan keterampilan intelektual yang mereka gunakan. Selama aktivitas ini, guru meminta siswa untuk mengkonstruksikan pikiran dan kegiatan mereka selama berbagai aktivitas sebelumnya. Aktivitas siswa selama pembelajaran berbasis masalah terlihat aktif dan kreatif serta memiliki semangat yang tinggi dalam memecahkan masalah yang diberikan. Belajar aktif dapat menumbuhkan sikap kreatif hidupnya dikemudian hari lebih berhasil, lebih dapat mengatasi persoalan di masyarakat sebab banyak persoalan dalam kehidupan sehari-hari dapat dipecahkan secara matematika.

\section{Kesimpulan}

1. Dari hasil perhitungan $\mathrm{F}^{*}=8,79$ dan $\mathrm{F}_{(\text {tabel })}=4,15$. Berarti $\mathrm{F}^{*} \geq \mathrm{F}_{(\text {tabel })} \cdot \mathrm{H}_{0}$ ditolak dan diterima $\mathrm{H}_{a}$. Artinya ada pengaruh positif (signifikansi) hasil belajar matematika siswa yang memperoleh model pembelajaran berbasis masalah lebih baik daripada hasil belajar matematika siswa yang memperoleh model pengajaran konvensional, diperoleh rata-rata hasil belajar matematika siswa yang memperoleh model pembelajaran berbasis masalah adalah 6,94 sedangkan rata-rata hasil belajar matematika siswa yang memperoleh model pengajaran langsung adalah 6,08".

2. Hasil sikap (respon) siswa diperoleh: (1) sebagian besar $(88,62 \%)$ siswa suka terhadap pelajaran matematika, (2) Sebagian besar (95\%) siswa sungguh-sungguh mengikuti pelajaran matematika yang dilakukan, (3) Sebagian besar (88\%) siswa suka terhadap model pembelajaran Problem Based Instruction, (4) Sebagian besar $(93,21 \%)$ siswa menyatakan bahwa model pembelajaran PBM bermanfaat; (5) Sebagian besar (88,92\%) siswa suka terhadap Lembar Kerja Siswa (LKS), Berdasarkan data tersebut, respon siswa positif terhadap pembelajaran PBM.

Rohani ${ }^{1}$ Indah Fitria Rahma², Nurlina Ariani Hrp

Meningkatkan Hasil Belajar Siswa Kelas VIII dengan Metode Guided Discovery Learning

di MTs Islamiyah Kotapinang 
Jurnal Pembelajaran dan Matematika SIGMA (JPMS)

Vol 5 (No 1) 2019

\section{Daftar Pustaka}

[1] Sanjaya, Dr. Wina. (2005). Pembelajaran dalam Implementasi kurikulum Berbasis Kompetensi. Jakarta: Prenada Media.

[2] Slameto, (2013). Belajar dan Faktor-Faktor yang Mempengaruhi. Jakarta: Rineka Cipta

[3] Ruseffendi, E.T. (1998). Dasar-dasar Penelitian Pendidikan dan Bidang Non Eksakta Lainnya. Semarang : IKIP Semarang Press.

[4] Fahmi, Irham. 2012. Analisis Kinerja Keuangan. Bandung: Alfabeta.

[5] Suparno, P. (2001). Filsafat Konstruktivisme dalam Pendidikan. Yogyakarta: Kanisius. 